\title{
THE IMPACTS OF CORRUPTION ON ATTRACTING FOREIGN DIRECT INVESTMENT
}

\author{
Najibullah Zaki \\ Public Policy Department \\ Public Policy and Administration Faculty, Kabul University \\ Kabul City, Kabul, Afghanistan \\ najeebzaki@gmail.com
}

\begin{abstract}
Investment is a macroeconomic variable and its well-known as the engine of economy that boosts economic growth, economic development and sustainable development. Investment plays an important role in the livelihood welfare of citizens. All economies require different types of investments, particularly Foreign Direct Investment/ FDI in different sectors. Based on empirical researches, mostly FDI has positive impacts on the sustainable economic growth of the host economies. On the one hand, FDI transfers technologies, skills, innovations, experiences, techniques and knowledge to the host economies. On the other hand, it provides host economies with stable financial resources for a long period of time. Thus, it is the responsibility of governments to open their borders toward FDI inflows in order to attract this valuable financial resource. Despite the fact that countries require FDI, but corruption is one of the main obstacles against it.

Theoretically, there is a negative correlation between corruption and FDI inflows. In other words, corruption negatively impacts the FDI inflows and decreases FDI volume. Because, corruption increases costs and decreases benefits of FDI, corruption deteriorates the competitive trade environment; corruption discourages foreign investors through protecting domestic investors and corruption negatively effects the productivity of foreign investors. In practice, although most of the empirical researches showed that corruption negatively impacts the FDI flows, some empirical researches also confirmed that there is a positive correlation between corruption and FDI flows. Hence, countries are responsible in fighting against corruption to attract more FDI and in return benefit their sustainable economic growth.
\end{abstract}

Keywords: Corruption, Investment, Domestic Investment, Foreign Investment, Foreign Direct Investment.

DOI: $10.21303 / 2504-5571.2020 .001368$

\section{Introduction}

Investment is a macroeconomic variable that works as the engine for sustainable economic growth, economic development, sustainable development, and overall production level of economy in the country. It is derived from savings of the citizens in a country. The balance between investments and savings constitutes an important basis for having a sound and strong economic system. While the imbalance between investments and savings means a surplus or shortage of investments compared to the savings. This imbalance between these two variables (savings and investments) can be risky for the whole economic system. On the one hand, if a country has more savings rather than investments this can be hypothesized that the economy does not have enough capacity to absorb all its resources. Thus, for the sake of efficient use, the extra resources should be invested abroad. On the other hand, if a country has fewer savings compared to the investments, the high officials of the certain country are responsible for opening their borders for the foreign investors.

\section{1. Definitions and Types of Foreign Direct Investment}

In fact, there are two main types on foreign investments, such as foreign direct investment and foreign indirect investment. Foreign Direct Investment (FDI) is defined as "an investment, made by a company or entity, based in one country, into a company or entity, based in another country" [1]. While Foreign Indirect Investment is defined as buying securities of a company by a foreign investor without any control or influence on its operations in the host country [2].

This paper discusses the impact of corruption on attracting FDI. This paper is in four parts: First, it introduces the topic and particularly describes the importance of FDI attraction on the economy. Second, it describes the importance and impacts of FDI. Third, it describes the results and findings about impacts of corruption on FDI inflows and finally it ends up with a conclusion. 


\section{Aim of research}

This paper is mainly focusing on three most important scenarios; evaluation of the term corruption, evaluation of the term foreign direct investment and impacts of corruption on attracting foreign direct investment. Therefore, the main purpose of the current paper is to evaluate impacts of corruption (theoretical or practical) on attracting foreign direct investment.

\section{Materials and Methods}

\section{1. Importance of Foreign Direct Investment}

Foreign Direct Investment provides stable financial resources with a long time horizon that can play an important role in the economic growth, economic development and sustainable development of a host economy. FDI is crucial for all countries, especially developing countries (developing economies) compared to the developed economies (developed countries). Because, on the one hand, the domestic resources of developing countries are not sufficient to meet their needs and requirements and on the other hand, the economic problems of developing countries like unemployment rate, high inflation rate, low investment, low production, low economic growth, deficit of trade balance, unequal income distribution, low savings, low consumption, low living standards and high poverty rate is much higher compared to the developed economies. Thus, it is essential for developing economies to attract more FDI in order to meet their wishful requirements. FDI transfers knowledge, techniques, skills, technologies and innovations to the host economies. Thus, FDI can impact the macroeconomic and microeconomic variables of the host economies in spheres of business, competition, innovations, technology, growth, employment, development and citizen's welfare areas [3].

\section{2. The Impacts of Foreign Direct Investment}

As per evidences, the impacts of FDI on macroeconomic variables of the countries are mostly positive. For instance, Classens (1993) conducted his research on "different forms of mobilization of financial resources", his findings showed that FDI is the best form of financing for the developing economies [4]. In other words, if we compare different forms of financing resources like FDI and domestic financing, according to Classens (1993) the best way of financing developing economies is FDI. Laura Alfaro (2003) in her empirical research on "Foreign Direct Investment and Growth: Does the Sector Matter?" collected cross - countries panel data for the period of 19811999 and found that FDI has positive impact on manufacturing sector [5]. Beatrice Farkas (2012) in a research on "Absorptive Capacities and the Impact of FDI on Economic Growth" showed that "contribution of FDI to economic growth is positive and significant depending on the level of human capital and the development of financial markets, but its presence in developing countries must complement rather than substitute a set of other growth determinants." [6]. In all above studies one can observe that FDI has a positive role on the whole economy of a country.

Mostly impact of FDI on sustainable economic growth is positive, but when FDI works as substitutes for domestic investments or when it occurs in the primary sector, such as an agriculture sector, it could have negative consequences on the sustainable economic growth of a country. For instance, according to Misun and Toms1k (2002) with evidences from Poland in 1990s, "If FDI crowds out domestic investment, total private investment rises by less than the FDI and the benefits for the country are reduced." [3]. Alfaro (2003) also argued that FDI in the primary sector has negative consequences on economic growth of a country [5]. From above studies it is obvious, that sometimes FDI has negative consequences on sustainable economic growth of a host country in the most cases.

\section{Result}

Mostly corruption is defined as "the abuse of public power for private benefit" [7]. Corruption is an illegal activity which negatively impacts the business environment, economic growth, economic development, citizen's welfare, FDI attraction, and the overall quality of governance in a country. Typically corruption occurs in two major types such as petty (administrative) and grand (political) and it affects the performance of a government to achieve its predetermined goals and 
objectives. As well as, corruption occurs in other forms like bribery, extortion, embezzlement, money laundering, forgery, fraud and nepotism in public and private offices. Corruption works as a cancerous disease and it negatively impacts FDI inflows (FDI attraction) in a host economy. The main purpose of FDI inflow is profit maximization and the major challenge against this profit maximization is assessed corruption.

In theory, corruption has a direct impact on the cost of FDI in host economies [8]. On the one hand, in a corrupt system the foreign direct investors require to pay money as a bribe to the corrupt officials in order to run their businesses. The reasons for this payment are due to the long registration processes of FDI, licensing requirements, taxation issues and long bureaucratic procedures in the host economies. When foreign investors pay money as a bribe to the corrupt officials it significantly increases the costs of doing their business. According to the Transparency International report, more than half of the respondents in a survey complained that corruption has increased their costs of doing business by 10 percent [9]. Thus corruption increases costs of doing business and it is a challenge in FDI attraction in a host country.

In addition, theoretically corruption affects the competition environment in the host economies and in turn it affects the FDI attraction. An FDI is beneficial where the competition environment is protected by the government under the certain regulations and supported by the officials. When foreign investors want to invest in a host country, firstly they want to maximize their profits by investing in a well manageable environment. Thus, foreign investors want to get market power gradually by raising their market shares that leads to the profit maximization. Since the FDI transfers new technologies, knowledge, experiences and skills to the host countries, it will be beneficial to compete with the domestic investors in a regulated and protected environment for FDI. Thus, corruption negatively impacts the quality of competition and government intervenes in the market. This means that corruption deteriorates the competitive environment and reduces the FDI inflows in the host countries by the low protected environment.

Moreover, in theory, corruption protects the domestic investments against FDI and in turn it reduces the FDI attraction in the host countries. In other words, corruption discriminates between domestic investments and FDI in terms of the origin through the violation of the national treatment principle of WTO [10]. Corruption increases the opportunity cost for businesses by foreign investors compared to the domestic investors, particularly during the registration, licensing and tax procedures. In turn, corruption decreases FDI attractiveness of host economies, because under a corrupt system foreign investors pay an additional amount of money as a bribe to the corrupt officials otherwise they will suffer from long bureaucratic procedures that increases their opportunity cost. But domestic investors are familiar with the system and they do not pay such an additional amount of money as a bribe to the corrupt officials and they will not suffer from long bureaucratic procedures (opportunity cost). In turn, corruption negatively affects the prices of goods for foreign investors and it reduces the FDI attraction in the host country.

Furthermore, corruption increases the risks of doing business and decreases the confidence level of foreign investors. In turn, corruption reduces the attractiveness of FDI in the host economy [11]. A corruption level is one of the indicators of measuring the governance quality in a country and it can directly impact the FDI attraction in the host economy. The low level of corruption can be hypothesized as a symptom of better governance and the high level of corruption can be hypothesized as a symptom of bad governance. In bad governance, the foreign investors' feel high risk and low confidence in front of their business. That is why they prefer to not invest their money in a host economy with bad governance. It means that, bad governance creates high risk and low confidence level for foreign investors. Thus, foreign investors do not invest their money in a host economy with high risk and low confidence level. In turn, bad governance reduces the FDI attraction in the country.

In addition, corruption reduces the productivity, resource allocation, quality of goods and services, innovations and efficiency of FDI and in turn it reduces the FDI attraction in the host economies [8]. More specifically corruption works as a cancerous disease that negatively impacts the volume of FDI in the host economies.

In practice, most of the empirical researches also showed that there is a significant negative correlation between a level of corruption and FDI attraction in the host economies, but some re- 
searches also showed that there is a positive relationship between these two variables. For instance, Ali Al - Sadig (2009) in his empirical research on "The Effects of Corruption on FDI Inflows", with panel data from 107 host economies for the period of 1984 - 2004 showed that there is a strong negative correlation between corruption and FDI attraction [12]. He argued that one point decrease in corruption causes 11 percent increase in FDI per capita inflows [12]. In addition, Aye Mengistu Alemu (2012) in an empirical research on "Effects of Corruption on FDI Inflow in Asian Economies", with a panel data from 16 Asian host countries over the period of 1995 - 2009 showed that there is a strong negative correlation between corruption and FDI attraction (1 percent increase in corruption decreases 9.1 percent FDI) [8]. Moreover, Rahim M. Quazi (2014) in an empirical research on "Corruption and Foreign Direct Investment in East Asia and South Asia: An Econometric Study" with panel data from all East Asia and South Asia economies over the period of 1995-2011 argued that there is strong negative correlation between corruption and FDI attraction in the host economies [13].

As mentioned above, in practice, some empirical researches show that corruption positively affects the FDI attraction in host economies. This means that foreign investors by paying some additional amount of money (bribe) avoid the opportunity cost and other types of cost in their businesses. For instance, Katrina Pla Gutierrez (2015) conducted an empirical study on "The Effect of Corruption on FDI in Argentina", she collected panel data over the period of 1995-2013 and her findings showed that in Argentina there is a positive correlation between corruption and FDI [9]. Because, in Argentina FDI is mostly attracted in natural resources and since natural resources are limited around the world, so it is beneficial for foreign investors to keep their investments in this area. In addition, Eagger and Winner (2005) conducted their empirical research on the relationship between corruption and FDI attraction, they collected panel data from a sample of 73 developed and developing economies over the period of 1995-1999 and their finding showed that there is a significant positive relationship between corruption and FDI attraction in the host economies [14].

\section{Conclusion}

As a result, currently investment is known as the engine of sustainable economic growth in the economy. Investment (domestic or foreign) plays an important role in the welfare of citizens. All economies require investments in different areas and in different types. However the importance of FDI is much higher rather than any other investments. Based on empirical researches, mostly FDI has positive impacts on the sustainable economic growth of the host economies. On the one hand, FDI transfers technologies, skills, innovations, experiences, techniques and knowledge to the host economies. On the other hand, it provides host economies with stable financial resources for a long period of time. Thus, it is the responsibility of governments to open their borders toward FDI inflows in order to attract this valuable financial resource. Despite the fact the countries require FDI, but corruption is one of the main obstacles against it.

Theoretically, there is a negative correlation between corruption and FDI attraction in the host economies. In other words, corruption negatively impacts the FDI inflows and decreases the volume of FDI attraction. Because corruption increases the costs and decreases the benefits of FDI (return on investment), corruption deteriorates the competitive environment; corruption protects the domestic investors against foreign investors and corruption impacts the productivity of foreign investors. In practice, although some empirical researches showed that there is a positive correlation between corruption and FDI, most of the empirical researches also showed that corruption negatively impacts the FDI attraction. In conclusion, one would infer that corruption is a cancerous phenomenon and countries are responsible for fighting this illegible phenomenon in order to attract more FDI and in turn benefit their sustainable economic growth.

\section{References}

[1] Chen, J. (2020). Foreign Direct Investment (FDI). Investopedia. Available at: http://www.investopedia.com/terms/f/fdi.asp

[2] Sadeq, R., Rustami, M., Padam, S. S. (2014). Evaluation Of Factors Affecting FDI In The Iranian Oil And Gas Industry. Available at: http://www.nioc.ir/portal/File/ShowFile.aspx?ID=d5c45c43-89c2-41a7-b31f-b39f89cfc6ba 
[3] Behbudi, D., Karami, A., Mamipour, S. (2010). Natural resource abundance, human capital and economic growth in the petroleum exporting countries. Journal of Economic Development, 35 (3), 81-102. doi: http://doi.org/10.35866/caujed.2010.35.3.004

[4] Dr Abu Al-Qasem, M. (2003). Analysis Of The Role Of Foreign Investment In Economic Growth. Available at: https://jte.ut.ac. ir/article_13286_83ff2d6787a89320cbe81c4a0e9ec2ee.pdf

[5] Alfaro, L. (2003). Foreign Direct Investment And Growth: Does The Sector Matter? Available at: http://www.grips.ac.jp/ teacher/oono/hp/docu01/paper14.pdf

[6] Beatrice, F. (2012). Absorptive Capacities And The Impact Of FDI On Economic Growth. Discussion Papers. Available at: https://www.diw.de/documents/publikationen/73/diw_01.c.396264.de/dp1202.pdf

[7] Vito, T. (1998). Corruption Around The World: Causes, Consequences, Scope, And Cures. Budapest: IMF. Available at: https:// www.imf.org/external/pubs/ft/wp/wp9863.pdf

[8] Mengistu, A. A. (2012). Effects Of Corruption On FDI Inflow In Asian Economies. Seoul Journal of Economics, 25 (4), 387-412. Available at: http://s-space.snu.ac.kr/bitstream/10371/79634/1/25-4_2_Aye_Mengistu_Alemu.pdf

[9] Pla, G. K. (2015). The effect of corruption on fdi in Argentina: has corruption acted as a negative determinant discouraging FDI? Available at: https://ddd.uab.cat/pub/tfg/2015/136831/TFG_kplagutierrez.pdf

[10] Investment Process In Afghanistan: Challenges And Incentives (2013).

[11] Onyinye, U. (2014). The Effect Of Corruption On Foreign Direct Investments In Developing Countries. The Park Place Economist. Available at: http://digitalcommons.iwu.edu/parkplace/vol22/iss1/17

[12] Al-Sadig, A. (2009). The Effects Of Corruption On FDI Inflows. Cato Journal, 29 (2). Available at: https://www.ciaonet.org/ attachments/14861/uploads

[13] Quazi, R. M. (2014). Corruption And Foreign Direct Investment In East Asia And South Asia: An Econometric Study. International journal of economics and financial issues, 4 (2), 231-242. Available at: https://econjournals.com/index.php/ijefi/article/ view/695

[14] Amarandei, C. M. (2016). Corruption and Foreign Direct Investment. Evidence from Central and Eastern European states. CES Working Papers, V (3), 311-322. Available at: http://ceswp.uaic.ro/articles/CESWP2013_V3_AMA.pdf 